\title{
Identification of pavement layers using a thermal probe
}

http://dx.doi.org/10.1590/0370-44672015680097

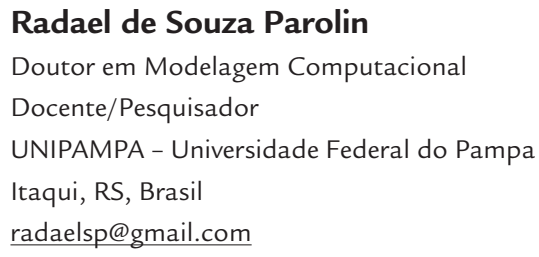

\section{Pedro Augusto Pereira Borges}

Doutor em Engenharia Mecânica

Docente/Pesquisador

UFFS - Universidade Federal da Fronteira Sul

Curso de Engenharia Ambiental e Energias

Chapecó, SC, Brasil

pedro.borges@uffs.edu.br

\section{Luciano Pivoto Specht}

Doutor em Engenharia Civil

Docente/Pesquisador

UFSM - Universidade Federal de Santa Maria

Centro de Tecnologia

Departamento de Transportes

Camobi, Santa Maria, RS, Brasil

luspecht@ufsm.br

\section{Identificação das camadas de pavimento utilizando sonda térmica}

\begin{abstract}
To obtain information about pavement structure, nowadays, destructive prospecting is carried out, interfering significantly with traffic. Proposed here in is a less destructive and invasive technique, whereby a thermal probe with temperature sensors is installed in the pavement. This process identifies the sources of heat to obtain the temperature distribution as a function of time and space at different depths; to solve the heat transfer problem in two dimensions and to estimate the thickness and thermal materials properties of each layer through the Inverse Problem. The Direct Problem has been modeled by a heat conduction equation and solved by Central Finite Differences, using the explicit method of time advancements. The Genetic and Memetic Algorithms have been efficient in estimating the thickness of the layers and they have presented little difference between the estimated values at each application. The proposed technique has been efficient in estimating the thickness in the tests with experimental pavements and it brings a new perspective for structural evaluation, with reduced pavement intervention and traffic interference.
\end{abstract}

Keywords: mathematical modeling; pavement layers; thermal probe.

\section{Resumo}

Para se obterem informações sobre a estrutura de pavimentos, atualmente, são realizadas prospecções significativamente destrutivas e intervenientes no tráfego. $O$ objetivo desse trabalho é desenvolver uma técnica de identificação das espessuras das camadas de pavimentos, que consiste na instalação de uma sonda térmica no pavimento, com sensores de temperatura e fontes de calor, para a obtenção da distribuição de temperatura em função do tempo e do espaço, em diferentes profundidades; na resolução do problema de transferência de calor em duas dimensões; e na estimação das espessuras e propriedades térmicas dos materiais de cada camada através do Problema Inverso. O Problema Direto foi modelado pela equação de condução do calor e resolvido com Diferenças Finitas Centrais, usando o método explícito de avanços temporais. Os Algoritmos Genético e Memético foram eficientes na estimação das espessuras das camadas e apresentaram pouca diferença entre os valores estimados a cada aplicação. A técnica proposta mostrou-se eficiente na estimação das espessuras nos testes realizados com pavimentos experimentais e traz uma nova perspectiva em avaliação estrutural, com reduzida intervenção no pavimento e interferência no tráfego.

Palavras-chave: modelagem matemática; camadas de pavimentos; sonda térmica.

\section{Introduction}

Road transport has a fundamental role in the world's social and economic development. Especially in Brazil, its importance is indisputable, since more than half of the cargo is transported on its highways. According to Medina and
Motta (2005), $60 \%$ of the cargo and $96 \%$ of the passengers are transported on the highways of this country. 
The Brazilian road network has an extension of $1,634,071 \mathrm{~km}$, with only $13 \%$ being paved. Out of the paved network, $64 \%$ of the roads are in a very bad, bad, or regular conditions, according to a research conducted by the $\mathrm{Na}$ tional Transport Confederation in 2013 (CNT, 2013). These deficiencies involve mainly the state of the pavements, the lack of road signs and the non-existence of roadsides.

The maintenance and rehabilitation of pavements are carried out after probing for their functional and structural conditions. The execution of probing is mandatory when there is no information available about the structure, construction history and degradation over the years (Brown, 1997; Bernucci et al.,

\section{Materials and methods}

The research planning consisted with the installation of a thermal probe in two experimental pavements, one rigid and one flexible, in order to acquire the temperature data over the time. In this technique, the pavement is drilled only at one point, easily restorable. The monitored experimental data are compared with the temperature distribution calculated with the heat transfer Direct Problem and thick-
2006; Papagiannakis and Massad, 2008). These probings require equipment and specialized personnel, making the procedures expensive, and interfering with the level of traffic and road serviceability.

The thickness of the layers and the identification of the materials composing the pavement are essential information and, in some cases, unavailable for decision-making. To identify the thickness of the layers, there are non-destructive techniques based on the georadar (Saarenketo and Scullion, 2000; Fontul et al.,2007). However, it is still little used in Brazil due to the equipment cost and the complexity of the data analysis. The study of new techniques for probing the pavement which provide lower cost, along with less invasion and traffic interference, are relevant to the improvement of existing techniques.

Recently, several studies involving the pavement temperatures have been presented on literature, focusing the thermal influence on pavement behavior and performance (Becker et al.,2014; Wang et al., 2014); as well, there are studies involving mathematical modeling to solve advanced problems on pavement engineering (Broutin et al.,2013; Specht and Khatchatourian, 2014)

The objective of this study was to develop a technique to estimate alreadyconstructed-pavement layer thickness by using a thermal probe and to process the data achieved through mathematical modeling, the results of which are presented herein.

\subsection{Experimental pavements and thermal probe}

The temperature measurement $0.5 \mathrm{~m}$ wide, $0.5 \mathrm{~m}$ long and $0.85 \mathrm{~m}$ deep) experiments were carried out on experimental pavements (two experimental pavements, one rigid and one flexible,
Civil Engineering Laborator was monitored on the two pavements ness is estimated through resolution of the Inverse Problem. The Direct Problem is composed of the heat conduction equation, with boundary conditions of the first kind and is solved by the Central Finite Differences Method, with the explicit scheme of temporal advancements, which contains the thermal parameters of thermal conductivity and diffusivity, besides the thicknesses of the pavement layers. The

Inverse Problem has been implemented with the Genetic and Memetic Algorithms, estimating the thermal parameters and the thicknesses, minimizing the difference of the experimental temperatures calculated with the Direct Problem. The optimization methods used were chosen because their applicability in estimating several parameters simultaneously, such is the case in this work.

through a thermal probe (temperature sensors - thermocouples - at various depths and sources of heat in the deepest layers), composed of 9 temperature

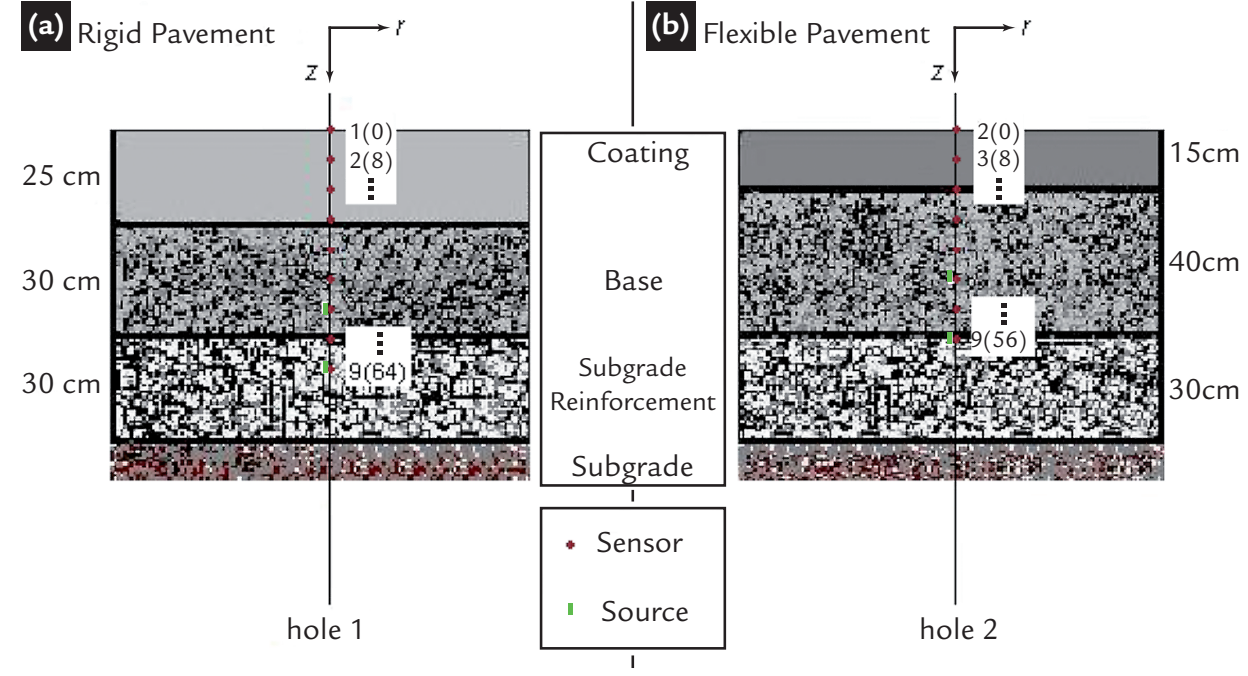

sensors, put into holes of $0.012 \mathrm{~m}$ of diameter by $0.64 \mathrm{~m}$ of depth for the rigid pavement and $0.56 \mathrm{~m}$ of depth for the flexible pavement, just like shown in Fig. 1. The two sources of heat are resistors of $2.2 \Omega$, fed with tension of $2 \mathrm{~V}$ each.

The experimental pavements are composed of the following layers:

Subgrade: composed of a basalt residual soil, clayey and porous, typical
Figure 1

Scheme representing the pavements (the first number indicates the sensor and the second, the depth in $\mathrm{cm}$ )

of the Ijuí region.

Subgrade reinforcement: granular base composed of basalt cracked rock, with thickness of $30 \mathrm{~cm}$. The cracked rock layers constitute big non- 
uniform forms, not fitting perfectly when the layer is compacted, allowed the water drainage.

Base: with a thickness of $30 \mathrm{~cm}$ on the rigid pavement and $40 \mathrm{~cm}$ on the flexible pavement, it is composed of dense granular gravel with a maximum size of $19 \mathrm{~mm}$; this layer is responsible for the distribution of the traffic loading.

The coatings are of two types: Portland Cement Concrete (rigid pave-

\subsection{Uncertainty analysis of the temperature measurements}

The uncertainty in the temperature measurements was determined by considering the calibration and procedure errors. The calibration error was evaluated using a calibrated reference thermometer. The reference thermometer and the temperature sensors were put into the water at different temperatures, until they reached the thermal balance. A straight

Where, I : temperature measurement uncertainty $\left({ }^{\circ} \mathrm{C}\right)$,

For each thermocouple corresponds an uncertainty. The S3 thermo-

\subsection{Mathematical model of heat transfer}

The heat transfer on the pavements is basically influenced by the surface conditions and by the sources of heat installed in the thermal probe. The surface conditions are practically the same for each point in

line adjustment was generated on the basis of the temperatures measured by each thermocouple. The standard distribution deviation $\left(\sigma_{c}\right)$ of the differences between the temperatures measured by the thermocouple and the thermometer was used as a calibration error.

For the analysis of the procedure error, temperature measurements were

$$
I= \pm \sqrt{\sigma_{c}^{2}+\sigma_{r}^{2}}
$$

$\sigma_{c}$ : calibration standard deviation of each thermocouple $\left({ }^{\circ} \mathrm{C}\right)$ and

couple has presented the biggest one, $I= \pm 0.66^{\circ} \mathrm{C}$, and the $\mathrm{S} 7$ thermocouple, a circle having radius $\mathrm{R}$ with the center in the central hole. The heat generated by the probe diffuses in the pavement with an angular symmetry, around the central axis. To model such characteristics of the ment): with $25 \mathrm{~cm}$ of thickness; and Bituminous (flexible pavement): it has a thickness of $15 \mathrm{~cm}$ cold mix and a sealing cover (asphaltic emulsion bath on the coating), with aims to seal the pavement, making it impermeable.

carried out for each temperature sensor with the thermal probe, repeating the steps of the definitive experiment, keeping the same thermal conditions at each measurement. On the basis of these measurements, the repetition standard deviation $\left(\sigma_{\mathrm{r}}\right)$ was calculated. The measurement uncertainty of each thermocouple has been calculated by Eq. 1 .

$\sigma_{r}$ : procedure standard deviation of each thermocouple $\left({ }^{\circ} \mathrm{C}\right)$.

the smallest one, $I= \pm 0.31^{\circ} \mathrm{C}$.

thermal phenomena involved, used as the Heat Conduction Differential Equation with sources (ÖZISIK, 1993), in cylindrical coordinates, for the two-dimensional case, in the form of Eq. 2.

$\frac{1}{\alpha_{i}} \cdot \frac{\partial T}{\partial t}=\frac{\partial^{2} T}{\partial z^{2}}+\frac{1}{r} \cdot \frac{\partial}{\partial r}\left(r \cdot \frac{\partial T}{\partial r}\right)+\frac{1}{k_{i}} \cdot g$

The boundary and initial conditions presuppose that the blocks of

pavements are cylinders with a $R$ radius and an $H$ height

$$
\begin{aligned}
& T(r, 0, t)=T_{S}(t) \quad \text { where } 0<t<t f \\
& T(r, H, t)=T_{H} \quad \text { where } 0<t<t f \text { and } H \text { the maximum depth } \\
& T(R, z, t)=T_{R}(z, t) \text { where } 0<t<t f \text { and } R \text { the maximum radius } \\
& T(r, z, 0)=T_{0}(r, z) \text { where } 0<r<R \text { and } 0<z<H
\end{aligned}
$$

Where, $T$ : temperature $\left({ }^{\circ} \mathrm{C}\right)$, $z$ : depth $(m)$,

$r:$ radius $(m)$,

$t$ : time $(s)$,

$t f$ : experiment final time $(s)$,

Equations (2-6) constitute the mathematical model of heat transfer on

\subsection{Parameter estimation algorithms}

The inverse problem consists in estimating parameters of the direct problem, through calculation algorithms, whose objective is to minimize the differences $\alpha_{i}$ : thermal diffusivity of $\left(\mathrm{m}^{2} / \mathrm{s}\right)$ layer $i$, $g$ : heat source volumetric density $\left(\mathrm{W} / \mathrm{m}^{3}\right)$, $k_{i}$ : thermal conductivity in the source of heat of $\left(\mathrm{J} / \mathrm{ms} \mathrm{s}^{\circ} \mathrm{C}\right)$ layer $i$, $T_{0}$ : initial condition $\left({ }^{\circ} \mathrm{C}\right)$,

the pavement, called Direct Problem in this work.

between the temperatures measured and calculated with the direct problem. For this, two algorithms, Genetic and Memetic, were used. The Genetic Algorithm has
$T_{S}$ : temperature on the surface $\left({ }^{\circ} \mathrm{C}\right)$, $T_{H}$ : temperature at the end of the third layer $\left({ }^{\circ} \mathrm{C}\right)$, $T_{R}$ : temperature in the pavement maximum radius $\left({ }^{\circ} \mathrm{C}\right)$.

been described by Holland (1975), Goldberg (1989) and Leandro et al. (2008), and the Memetic Algorithm, by Moscato (1989), Britto (2007) and Leandro et al. 
(2008), and they have been adapted to

1st Step:

Considering each chromosome $\mathrm{Cro}_{i}=\left[\right.$ Gene1 $_{i}$ Gene $_{i} \ldots$... Gene $\left.(n p)_{i}\right]$ of $n p$ parameters, one generates the

2nd Step:

Evaluation of each chromosome is made through the $R^{2} \geq R_{o t}$ determina-

\section{3rd Step:}

The population is ordered by aptitude according to the determination coef-

\section{4th Step:}

The chromosomes for the crossovers are selected through a normalized geomet-

where $q$ represents the unitary rate of the chromosome with the greatest aptitude, $P$

5th Step:

New chromosomes (son) are generated by

Cro1 and Cro2 are the chromosomes selected for the crossover, $r_{j}$ and

6th Step:

New chromosomes (sons) generated by

$$
\text { Son } 3=\left\{\begin{array}{lll}
r_{j} \cdot \operatorname{Cro~} 3_{i}+\left(1-r_{j}\right) L I_{i} & \text { se } & r_{k} \leq 0,5 \\
r_{j} \cdot \operatorname{Cro} 3_{i}+\left(1-r_{j}\right) L S_{i} & \text { se } & r_{k}>0,5
\end{array}\right.
$$

where $\mathrm{CrO} 3$ is the chromosome selected for the crossover, $r_{j}$ and $r_{k}$ are random coeffi-

7th Step:

New chromosomes (child) by uniform mutation. The genes randomly selected through a $P M(\%)$ prob-

\section{8th Step:}

Evaluation of each new chromosome is

\section{9th Step:}

The population is ordered by aptitude according to the determination coefficient of

\section{0th Step:}

A Local Search (this step exists only for the Memetic Algorithm) is made at initial population, each gene being $\operatorname{Gene}(p)_{i}=L I_{i}+r_{i}\left(L S i-L I_{i}\right)$ where $L I_{i}$ and $L S_{i}$ are the inferior and superior

tion coefficient, where $R_{o t}$ is the stopping criterion.

ficient of each chromosome. The best chromosomes are then selected to start

ric ranking, according to the aptitude of each chromosome, given by Eq. 7:

$$
\text { ps }(i)=\frac{q(1-q)^{\text {rank }(i)-1}}{1-(1-q)^{P}}
$$

the population size, $\operatorname{rank}(i)$ of the chromosome position to be classified in descend- following steps:

limits, respectively, of the $p$ parameter, and $r_{i}$ a random coefficient.

the evolution process.

ing order by aptitude and $p s(i)$ is the probability of selection of the chromosome $i$. arithmetic crossover:

$$
\begin{aligned}
& \text { Son } 1=r_{j} \cdot \operatorname{Cro} 1_{i}+\left(1-r_{j}\right) \operatorname{Cro} 2_{i} \\
& \text { Son } 2=r_{k} \cdot \operatorname{Cro} 2_{i}+\left(1-r_{k}\right){\operatorname{Cro~} 1_{i}}
\end{aligned}
$$

$r_{K}$ are random coefficients. cients, $L I_{i}$ and $L S_{i}$ are the inferior and superior limits, respectively, of the parameters.

ability of population mutation are replaced by any other value inside the problem search space, just like the

made through the $R_{i}^{2} \geq R_{o t}$ determination

each chromosome. The best chromosomes are then selected.

each number of pre-defined generations. This local search may be a parameter one that generated each gene of the initial population.

coefficient, where $R_{o t}$ is the stopping criterion.

estimate method like the Newton's Method, the Quasi-Newton's Method, 
the Levenberg-Marquardt's Method or another one. For solving the proposed

\section{1th Step:}

When the local search has been carried out, another evaluation of each chromo-

\section{2th Step:}

The evolution process is repeated from the 4 th to the 11th steps until it meets

\section{Results and discussions}

The proposed parameter estimate problem comprises the search for seven parameters in the resolution of the Inverse Problem, which makes it a highly complex problem due to the range

Table 1

Defined characteristic data and demands of the algorithms for the Rigid Pavement and for the Flexible Pavement

The proposed method has been applied to data monitored on both a rigid and flexible pavement as a form of testing them with different layer thicknesses and material. Table 2 presents the experimental data of the rigid and flexible pave-

problem the Levenberg-Marquardt's Method (Özisik and Orlande, 2000)

some is made, together with the ordination by aptitude and the selection of the

the $R^{2}{ }_{i} \geq R_{\text {ot }}$ stopping criterion in some of the evaluations or a maximum num-

of possible solutions to the problem, and justifies research for an efficient estimate algorithm. The results are presented and discussed for each type of pavement.

\begin{tabular}{|c|c|c|c|c|}
\hline \multirow{2}{*}{ Definitions } & \multicolumn{2}{|c|}{ Genetic Algorithm } & \multicolumn{2}{|c|}{ Memetic Algorithm } \\
\hline & Rigid Pavement & Flexible Pavement & Rigid Pavement & Flexible Pavement \\
\hline $\begin{array}{l}\text { Search Range } \alpha_{i} \\
\left(\mathrm{~m}^{2} / \mathrm{s}\right)\end{array}$ & $1 \cdot 10^{-7}-1 \cdot 10^{-6}$ & $1 \cdot 10^{-7}-1 \cdot 10^{-6}$ & $1 \cdot 10^{-7}-1 \cdot 10^{-6}$ & $1 \cdot 10^{-7}-1 \cdot 10^{-6}$ \\
\hline $\begin{array}{c}\text { Search Range } \mathrm{k}_{i} \\
\left(\mathrm{~J} / \mathrm{ms}^{\circ} \mathrm{C}\right)\end{array}$ & $0.1-1$ & $0.1-1$ & $0.1-1$ & $0.1-1$ \\
\hline $\begin{array}{l}\text { Search Range } z_{1} \\
(\mathrm{~m})\end{array}$ & $0.2-0.3$ & $0.1-0.3$ & $0.2-0.3$ & $0.1-0.3$ \\
\hline $\begin{array}{c}\text { Search Range } z_{2} \\
(\mathrm{~m})\end{array}$ & $0.2-0.4$ & $0.3-0.5$ & $0.2-0.4$ & $0.3-0.5$ \\
\hline Initial Population & 1000 & 1000 & 100 & 100 \\
\hline $\begin{array}{l}\text { Population } \\
\text { Evolution }\end{array}$ & 100 & 100 & 10 & 10 \\
\hline $\begin{array}{l}\text { Max. } \\
\text { Generations }\end{array}$ & 10 & 10 & 10 & 10 \\
\hline Best $R^{2}$ & 0.99 & 0.99 & 0.99 & 0.99 \\
\hline $\begin{array}{c}\text { Arithmetic } \\
\text { Crossover (\%) }\end{array}$ & 40 & 40 & 40 & 40 \\
\hline $\begin{array}{c}\text { Crossover } \\
\text { Extremes (\%) }\end{array}$ & 30 & 30 & 30 & 30 \\
\hline $\begin{array}{c}\text { Prob. of } \\
\text { Mutation (\%) }\end{array}$ & 1 & 1 & 1 & 1 \\
\hline $\begin{array}{l}\text { Gen. Local } \\
\text { Search }\end{array}$ & - & - & 5 and 10 & 5 and 10 \\
\hline $\begin{array}{l}\text { It. Levenberg- } \\
\text { Marquardt }\end{array}$ & - & - & 3 & 3 \\
\hline
\end{tabular}

ments in the second and third columns and the results of the inverse problem.

The estimation of the third layer thickness $\left(z_{3}\right)$ is dependent on the first and second layer. Therefore, it is not considered as parameter estimation in was used.

best ones.

ber of pre-defined generations.

The Genetic and Memetic Algorithms application presupposes the definition of some characteristic data and demands, described in Table 1 , for both types of pavements. 
The Genetic and Memetic Algorithms are stochastic methods and, ie, they use different paths at each application, which may generate different solutions for the same conditions. For this reason, three applications of each method have been executed, adopting the average of the values obtained as the final estimated value. The average results obtained by the inverse problem and the respective standard deviation of each application are represented in Table 2 .

For the thicknesses, one observes that the standard deviations indicate that approximately $64 \%$ of the inverse prob- lem applications must give results in the $(-\sigma+\mu, \sigma+\mu)$ interval. The dispersion generated by the inverse problem executions does not present a significant inaccuracy in practical terms, for the standard deviations are in the order of millimeters. This justifies the need of execution and, at the very least, three applications and the adoption of the average as the final result. The comparison of the measured (experimental) thicknesses with the estimated ones shows that the maximum difference of $4 \mathrm{~cm}$ occurs in the third layer. In the first two layers this difference is at most $3.3 \mathrm{~cm}$. The values of diffusivity $\left(\alpha_{1}\right.$ and $\left.\alpha_{2}\right)$ and experimental thermal conductivity $\left(\mathrm{k}_{2}\right)$ presented in the second and third columns on Table 2 have been obtained from literature (Specht et al., 2008) and, therefore, they do not necessarily correspond to the real diffusivities of the monitored pavements. Such data must be understood, in this work, only as a reference. It is observed that the values estimated for the thermal diffusivity are in the same magnitude order of the literature data. It is also important to note that the thermal conductivities of the coating layers $\left(\mathrm{k}_{1}\right)$ were not estimated because there is no any heat source in those layers.

\begin{tabular}{|c|c|c|c|c|c|c|c|c|c|c|}
\hline \multirow{3}{*}{ Parameters } & \multirow{2}{*}{\multicolumn{2}{|c|}{$\begin{array}{l}\text { Experimen- } \\
\text { tal Data }\end{array}$}} & \multicolumn{4}{|c|}{$\begin{array}{l}\text { Applications of Genetic } \\
\text { Algorithm }\end{array}$} & \multicolumn{4}{|c|}{$\begin{array}{l}\text { Applications of Memetic } \\
\text { Algorithm }\end{array}$} \\
\hline & & & \multicolumn{2}{|c|}{ Rigid Pavement } & \multicolumn{2}{|c|}{$\begin{array}{l}\text { Flexible } \\
\text { Pavement }\end{array}$} & \multicolumn{2}{|c|}{$\begin{array}{c}\text { Rigid } \\
\text { Pavement }\end{array}$} & \multicolumn{2}{|c|}{$\begin{array}{l}\text { Flexible } \\
\text { Pavement }\end{array}$} \\
\hline & RP & FP & $\begin{array}{l}\text { Aver- } \\
\text { age }\end{array}$ & $\begin{array}{l}\text { St. } \\
\text { Dev. }\end{array}$ & $\begin{array}{l}\text { Aver- } \\
\text { age }\end{array}$ & $\begin{array}{l}\text { St. } \\
\text { Dev. }\end{array}$ & $\begin{array}{l}\text { Aver- } \\
\text { age }\end{array}$ & $\begin{array}{l}\text { St. } \\
\text { Dev. }\end{array}$ & $\begin{array}{l}\text { Aver- } \\
\text { age }\end{array}$ & $\begin{array}{l}\text { St. } \\
\text { Dev. }\end{array}$ \\
\hline$z_{1}(m)$ & 0.25 & 0.15 & 0.240 & 0.018 & 0.146 & 0.005 & 0.246 & 0.035 & 0.142 & 0.009 \\
\hline$z_{2}(m)$ & 0.30 & 0.40 & 0.301 & 0.028 & 0.385 & 0.012 & 0.327 & 0.021 & 0.390 & 0.009 \\
\hline$z_{3}(m)$ & 0.11 & 0.01 & 0.097 & 0.021 & 0.029 & 0.014 & 0.066 & 0.022 & 0.027 & 0.016 \\
\hline $\begin{array}{c}\alpha_{1}\left(10^{-7}\right) \\
\left(\mathrm{m} / \mathrm{s}^{2}\right)\end{array}$ & $\begin{array}{c}7.29 \\
\text { to } \\
7.95\end{array}$ & $\begin{array}{c}2.92 \\
\text { to } \\
5.43\end{array}$ & 9.446 & 0.286 & 8.755 & 0.789 & 8.963 & 0.540 & 7.653 & 0.392 \\
\hline$\frac{\alpha_{2}\left(10^{-7}\right)}{\left(\mathrm{m} / \mathrm{s}^{2}\right)}$ & $\begin{array}{c}5.38 \\
\text { to } \\
8.75\end{array}$ & $\begin{array}{c}5.38 \\
\text { to } \\
8.75\end{array}$ & 9.133 & 0.471 & 8.830 & 0.680 & 7.520 & 0.288 & 6.672 & 3.172 \\
\hline$\alpha_{3}\left(10^{-7}\right)$ & - & - & 8.275 & 1.776 & 6.231 & 0.558 & 5.652 & 1.632 & 6.172 & 0.891 \\
\hline $\mathrm{k}_{2}\left(\mathrm{~J} / \mathrm{ms}^{\circ} \mathrm{C}\right)$ & 0.7 & 0.7 & 0.712 & 0.030 & 0.852 & 0.062 & 0.714 & 0.041 & 0.776 & 0.063 \\
\hline $\mathrm{k}_{3}\left(\mathrm{~J} / \mathrm{ms}^{\circ} \mathrm{C}\right)$ & - & - & 0.440 & 0.006 & 0.315 & 0.004 & 0.451 & 0.004 & 0.305 & 0.016 \\
\hline $\mathrm{R}^{2}$ & - & - & 0.962 & 0.001 & 0.970 & 0.003 & 0.957 & 0.006 & 0.955 & 0.012 \\
\hline Time & - & - & $\begin{array}{l}1 \mathrm{~h} 7 \\
44 \mathrm{~s}\end{array}$ & $\begin{array}{l}12 \\
45 \mathrm{~s}\end{array}$ & $\begin{array}{l}46^{\prime} \\
41 \mathrm{~s}\end{array}$ & $5^{\prime} 10 \mathrm{~s}$ & $\begin{array}{l}16 \\
50 \mathrm{~s}\end{array}$ & $58 \mathrm{~s}$ & $\begin{array}{l}14 \\
3 \mathrm{~s}\end{array}$ & $40 \mathrm{~s}$ \\
\hline
\end{tabular}

The material identification from the values estimated by the inverse problem is more difficult, because there is a very broad variation in the values of these properties by virtue of the materials and the proportions of the materials in the composition of each layer. As an example, crushed rock thermal diffusivity may vary
Table 2

Estimate of parameters with the Genetic Algorithm and the Memetic Algorithm

by virtue of the type or rock used or else by the wet content.

The thicknesses and the thermal parameters estimated by the two meth- 
ods are very similar (as shown by Table 2) and, evidently, the charts generated with data estimated by the two methods present practically the same temperature distribution and thicknesses of layers. For this reason, only the charts for the experimental temperature, calculated by the Genetic Algorithm for each type of pavement are presented in Fig. 2 .

There are significant differences between the distribution of experimental and calculated temperature, as shown by Fig. 2. They are maximum (close to $5^{\circ} \mathrm{C}$ ) for points near the surface $(\mathrm{z}=0.1 \mathrm{~m})$, and are greater than the maximum uncertainty of temperature measurement $\left(\sim 0.66^{\circ} \mathrm{C}\right)$. The heat transfer model used is only conductive and, therefore, does not contemplate

Figure 2

Distribution of experimental and calculated temperature with the Genetic Algorithm: (a) Rigid Pavement (b) Flexible Pavement

\section{Conclusions}

The results obtained with the proposed technique have shown that:

1. The technique presents accuracy in the order of 3 to $4 \mathrm{~cm}$ to estimate the thickness of the layers of the pavements; possible convective currents of heated air by the sources of heat localized in the second and third layers. This heated air has increased the temperature measured by the sensors in the positions closer to the surface. Observe that the differences are much smaller in points next to the sources. In spite of the said differences, the proposed model describes the general behavior of the temperature, both in the region closer to the surface and close to the sources of heat.

Both algorithms have been rather efficient in estimating thicknesses for the available data. The smallest computational cost of the Memetic Algorithm, in relation to the Genetic one, shown in the last line of Table 2 , is due to the chosen condi- tions, shown in Table 1. If the algorithms were applied using the same conditions, the Genetic Algorithm, certainly, would present a better performance. However, if one uses a more restricted population, the Memetic Algorithm compensates with the local search and presents better execution times.

The thermal probe used, allowed the parameters were estimated satisfactorily using the inverse problem. However, the use of more sensors and heat sources of lower power, in order to reduce temperature gradients, may be investigated aiming to improve the probe, because it would increase the amount of temperature data for performing an efficient estimate of the parameters involved.
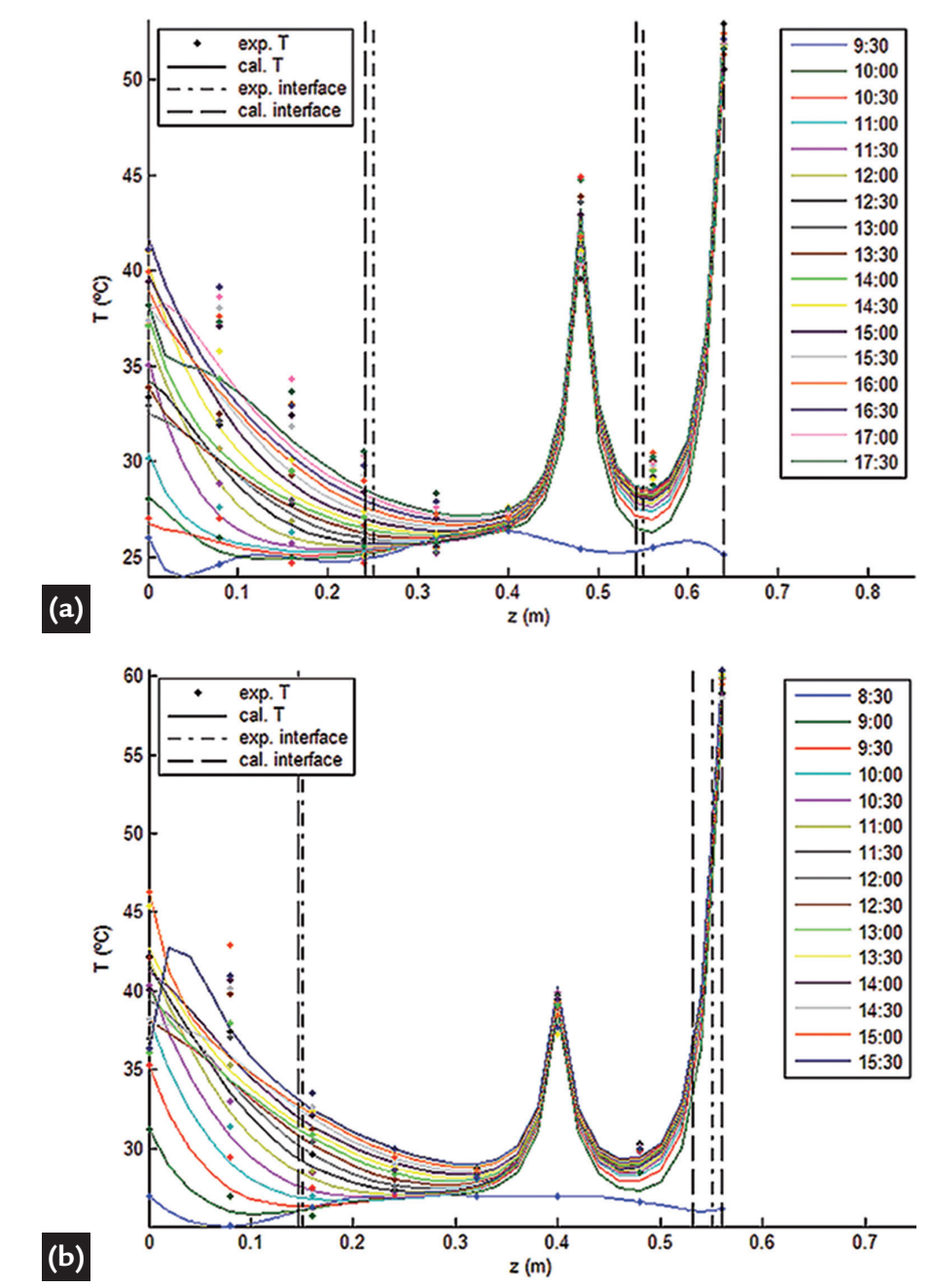

2. The identification of the materials using the values of thermal conductivity or diffusivity is not accurate, since the variability of these properties is very broad, depending on the material's particularity that constitutes each layer;

3. The Genetic and Memetic Algorithms have been efficient in estimating the thicknesses of the layers and presented little difference between the 
values estimated at each application. It is fundamental that at the very least, three applications of the inverse problem be executed, and the average between the estimated values be adopted as the final result. Considering the definition of the application demands for each method, the Memetic Algorithm has had a smaller computational cost. Even so, the application of the Genetic Algorithm has a vi-

\section{References}

able computational cost for the problem resolution proposal;

4. The proposed technique can be used in order to decrease the damage on pavement structures evaluation, using the thermal probe intercalated with the opening of the traditional probing wells. Such a combination would reduce the project cost and the need for traffic interventions.
Considering the viability in estimating the thicknesses, the technique proposed in this work brings a new perspective in the use of structural evaluation techniques. This technique does not need much equipment, nor much operational space (reducing traffic interferences) and it also dispenses experience for a complex analysis of the data obtained, for it is of easy implementation.

BECKER, M. L., MEEHAN, C. L., KALIAKIN, V. N. Finite element modeling of heat transfer in a reinforced concrete pavement. In: GEO-CONGRESS. 2014 p. 2942-2951.

BERNUCCI, L. B. MOTTA, L. M. G., CERATTI, J. A. P. , SOARES, J. B. Pavimentação Asfáltica: formação básica para engenheiros. Rio de Janeiro: PETROBRAS: ABEDA, 2006.

BRITTO, A. S. Identificação de sistemas utilizando algoritmos meméticos para estimação de parâmetros. Ijuí, Universidade Regional do Noroeste do Estado do Rio Grande do Sul - UNIJUÍ. Ijuí, 2007. (Dissertação de Mestrado).

BROUTIN M., MOUNIER D., FAUCHET, S. Advanced modeling for flexible pavement behavior under dynamical loadings. Airfield and Highway Pavement. p. 422-432, 2013.

BROWN, S. F. Achievements and challenges in asphalt pavement engineering. In: ISAP 8th International Conference of Asphalt pavements. Seattle. Proceedings. 1997.

Confederação Nacional dos Transportes. Pesquisa rodoviária 2013. Available at www.cnt. org.br.

FONTUL, S., ANTUNES, M.L., FORTUNATO, E., OLIVEIRA, M. Practical application of GPR in transport infrastructure survey. Advanced Characterization of Pavement and Soil Engineering Materials. Londres, 2007.

GOLDBERG, D. E. Genetic Algorithms in Search, Optimization, and Machine Learning. Boston: Addison Wesley Longman, 1989.

HOLLAND, J. H. Adaptation in Natural and Artificial System. Ann Arbor. (2 ed.). USA: The University of Michigan Press, 1975.

LEANDRO, G. V.; BORGES, A. P. B., SALVADORI, F., CAMPOS, M., RECH, C., CAMARGO, R. F. Optimal mathematical model of hall-effect sensor. In: INTERNATIONAL CONFERENCE ON ENGINEERING OPTIMAZATION. Anais... Rio de Janeiro, 2008.

MEDINA, J., MOTTA, L. M. G. Mecânica dos pavimentos. (2 ed.) Rio de Janeiro: UFRJ, 2005.

MOSCATO, P. On evolution, search, optimization, genetic algorithms and martial arts: towards memetic algorithms. Caltech Concurrent Computation Program, C3P Report 826, Pasadena CA, 1989.

ÖZISIK, M. N. Heat Conduction. New York: John Wiley \& Sons, 1993.

ÖZISIK, M. N., ORLANDE, H. R. B. Inverse heat transfer: fundamentals and applications. Taylor Francis. New York, 2000.

PAPAGIANNAKIS, A. T., MASSAD, E. A. Pavement design and materials. Hoboken: John Wiley \& Sons, 2008. 542p.

SAARENKETO, T., ScullionT. Road evaluation with ground penetrating radar. Journal of Applied Geophysics. v. 43, p.119-138, 2000.

SPECHT, L. P., BORGES, P. A.; Helmann, L. Determinação das propriedades térmicas de concretos asfálticos com diferentes tipos de ligantes. Revista Tecnologia (UNIFOR), v. 29, p. 198-210, 2008.

SPECHT, L. P., Khatchatourian, O. Application of artificial intelligence to modelling asphalt-rubber viscosity. The International Journal of Pavement Engineering, v. 15, p. 1-11, 2014.

WANG S. Y., ZHU Q., DUAN Y., SHANG, P. Unidirectional heat-transfer asphalt Pavement for mitigating the urban heat island effect. Journal of Materials in Civil Engineering. v.26 n.5, p. 812-821. 2014. 